\title{
HUBUNGAN PARITAS DENGAN TINGKAT KECEMASAN IBU HAMIL TRIMESTER III DALAM MENGHADAPI PERSALINAN
}

\author{
(Relationship Between Parity With The Level Of Anxiety In The Third Trimester Pregnant \\ Women Facing Childbirth .)
}

Triatmi Andri Yanuarini, Dwi Estuning Rahayu, Hanna Salehtra Hardiati

\section{ABSTRAC}

At each stage of pregnancy, pregnant women will experience different psychological processes. In the third trimester approaching delivery day there will be a new turmoil to deal with childbirth. With the approach of the time of delivery, a mother haunted by face anxiety the birth process. Birth experience is different from one woman to another, as well as between the first delivery with the next labor in women at the same or different women. Psychological changes dealing labor influenced by several factors, one of which is a factor that can be determined prior experience of parity. The purpose of this study was to determine is there a relationship between parity with the level of anxiety in the third trimester pregnant women facing childbirth .

This study uses cross-sectional correlation research design. The sample used by 30 respondents third trimester pregnant women with quota sampling technique. While the variables studied were parity using parity data collection table and anxiety levels using a questionnaire ( Scale HARS ). The data were analyzed using the Spearman correlation test with 95\% confidence intervals .

From the results of the study found the majority of respondents nullipara status $(43.33 \%)$ and their level of anxiety experienced third trimester pregnant women were mostly anxiety ( $43.33 \%$ ). After analysis of data by using the Spearman correlation test results obtained by the relationship between parity with the level of anxiety in the third trimester pregnant women facing childbirth.

\section{Keywords : Parity, Anxiety Levels, III Trimester Pregnancy, Childbirth}

\section{Pendahuluan}

Pada setiap tahapan kehamilan, ibu hamil akan mengalami proses kejiwaan yang berbeda. Pada trimester III yang sudah mendekati hari persalinan akan timbul gejolak baru untuk menghadapi persalinan dan perasaan tanggung jawab sebagai ibu pada pengurusan bayi yang akan dilahirkan. Saat ini kehidupan psikologis dan emosional ibu hamil dipenuhi oleh pikiran dan perasaan mengenai persalinan dan tanggung jawab sebagai ibu (Mochtar, Rustam. 1998 : 179).

Persalinan yang terjadi pada usia kehamilan 37-40 minggu disebut persalinan normal. Pada masa ini baik tubuh bayi maupun ibu sudah siap memasuki proses persalinan. Untuk itu, persiapan mental menuju persalinan sudah harus dimulai (Pusdiknakes, 2002). Walaupun persalinan adalah sebuah proses alami yang sekaligus menakjubkan dan sudah menjadi kodrat bagi seorang wanita untuk menjalaninya, tetapi seringkali ibu hamil tidak dapat menghilangkan rasa khawatir dan takut dalam menghadapi proses persalinan tersebut (Andriana, Evarini, 2007).

Proses melahirkan pada setiap ibu pasti berbeda-beda. Ternyata, selain penyebab yang bersifat klinis, suasana psikologis sang ibu yang tidak mendukung juga ikut andil mempersulit proses persalinan. Seperti ibu dalam kondisi cemas, khawatir dan takut yang berlebihan, hingga akhirnya berujung pada stres. Itulah sebabnya menjelang proses persalinan, ibu hamil membutuhkan ketenangan agar proses persalinan menjadi lancar tanpa hambatan. Semakin ibu tenang menghadapi proses persalinan maka persalinan akan berjalan semakin lancar (Pusparini, Wening, 2003). 
Perasaan takut, kehati-hatian atau kewaspadaan yang tidak jelas dan tidak menyenangkan adalah manifestasi cemas yang dapat dialami oleh setiap orang terutama pada ibu hamil yang menantikan proses persalinan. Penelitian di luar negeri menyebutkan $12 \%$ wanita menyatakan persalinan adalah saat-saat yang menyeramkan. Rasa cemas, takut dan sakit menimbulkan stres yang mengakibatkan gangguan proses persalinan, sehingga menghilangkan rasa cemas dan takut selama proses persalinan menjadi sangat penting (Aryasatiani, Ekarini, 2007).

Perubahan psikologis menghadapi persalinan dipengaruhi beberapa faktor, salah satunya adalah faktor pengalaman sebelumnya (Mahasiswi Prodi Kebidanan Negeri Jakarta, 2002). Menurut Kuswandi, semua orang selalu mengatakan bahwa melahirkan itu sakit sekali, oleh karena itu muncul ketakutan-ketakutan pada ibu yang baru pertama hamil dan belum memiliki pengalaman bersalin. Jika dilihat dari pengalaman melahirkan, ada dua golongan ibu yang diliputi rasa takut dan cemas menghadapi persalinan. Golongan pertama adalah perempuan yang sudah pernah melahirkan, namun mempunyai pengalaman yang tidak menyenangkan pada kehamilan dan persalinan sebelumnya. Golongan kedua adalah ibu hamil pertama kali dan belum pernah mempunyai pengalaman melahirkan sebelumnya, tetapi banyak mendengar tentang cerita-cerita dan pengalamanpengalaman yang menakutkan dari orang lain tentang proses persalinan (Arifin, Laili, 2007).

BPS Laili Fauziah, Amd. Keb. terletak di Desa Rejomulyo Kecamatan Kras Kabupaten Kediri. Dari studi pendahuluan yang telah dilakukan peneliti, dalam waktu satu minggu (7 hari) terdapat 21 ibu hamil trimester III yang melakukan pemeriksaan ANC, terdiri dari 10 nullipara, 7 primipara, 3 multipara, 1 grandemultipara. Dari wawancara yang dilakukan, seluruh ibu hamil nullipara dan sebagian besar ibu hamil primipara mengeluh merasa cemas menghadapi persalinan, sedangkan ibu hamil multipara dan grandemultipara mengatakan biasa saja atau tidak merasa cemas dalam menghadapi persalinan.

Dari data yang diperoleh menunjukkan cukup tingginya jumlah ibu hamil khususnya trimester III yang melakukan pemeriksaan ANC, macam paritas beragam dan tingkat kecemasan menghadapi persalinannyapun bervariasi.

Melihat fenomena yang terjadi di atas, peneliti tertarik untuk meneliti adakah Hubungan Paritas Dengan Tingkat Kecemasan Ibu Hamil Trimester III Dalam Menghadapi Persalinan di BPS Laili Fauziah, Amd.Keb. Desa Rejomulyo Kecamatan Kras Kabupaten Kediri.

\section{Metode}

Pada penelitian ini peneliti menggunakan desain penelitian korelasi dengan pendekatan Cross Sectional, yaitu mengkaji hubungan antar variabel dengan mencari, menjelaskan suatu hubungan, memperkirakan dan menguji berdasarkan teori yang ada, di mana data yang menyangkut variabel bebas atau variabel resiko dan variabel terikat atau variabel akibat, akan dikumpulkan dalam waktu yang bersamaan (Nursalam. 2003 : 84).

Populasi penelitian adalah seluruh ibu hamil trimester III yang melakukan pemeriksaan ANC di BPS Laili Fauziah, Amd.Keb. Desa Rejomulyo Kecamatan Kras Kabupaten Kediri, yaitu sebanyak 32 orang.

Besar sampel adalah 30 dicari dengan menggunakan rumus :

$$
\mathrm{n}=\frac{N}{1+N \cdot(d)^{2}}
$$

Keterangan :

$\mathrm{n}$ : Perkiraan jumlah sampel

$\mathrm{N}$ : Perkiraan besar populasi

d : Tingkat kesalahan yang dipilih $(d=0,05)$

(Nursalam. 2003 : 96)

Tehnik sampling yang digunakan teknik Quota Sampling. Variabel independent adalah paritas ibu hamil trimester III. Variabel dependent adalah tingkat kecemasan ibu hamil trimester III dalam menghadapi persalinan.

Alat ukur pada penelitian ini menggunakan lembar pengumpul data 
paritas untuk mengetahui paritas responden, sedangkan untuk mengukur tingkat kecemasan ibu hamil trimester III dalam menghadapi persalinan, digunakan kuesioner yang dimodifikasi dari skala HARS (Hamilton Anxiety Rating Scale).

Selanjutnya untuk menganalisa hubungan paritas dan tingkat kecemasan digunakan uji spearman rank. Untuk menentukan ditemukan ada tidaknya korelasi antara paritas dan tingkat kecemasan ibu hamil trimester III dalam menghadapi persalinan, kemudian hasilnya dikonsulkan ke tabel harga $\rho$ dengan interval kepercayaan 95\% $(\alpha 5 \%=0,05)$, dengan ketentuan sebagai berikut :

Jika $\rho \geq \rho$ tabel, maka hipotesis kerja diterima (ada hubungan antara paritas dengan tingkat kecemasan ibu hamil trimester III dalam menghadapi persalinan).

\section{Hasil}

Dari hasil penelitian yang telah dilakukan, diperoleh data bahwa dari 30 responden, 13 responden berstatus nullipara (43,33\%), 9 primipara (30\%), 6 multipara (20\%), dan 2 grandemultipara (6,67\%).

Tingkat kecemasan responden didapatkan hasil 30 responden, 9 responden mengalami kecemasan ringan (30\%), 13 responden mengalami kecemasan sedang $(43,33 \%)$, dan 8 responden mengalami kecemasan berat $(26,67 \%)$.

Dari analisa data dengan Uji Spearman Rank, didapatkan hasil nilai $\rho x y=0,553$, kemudian dikonsulkan ke tabel harga kritik dengan taraf signifikasi $95 \%$ ( 0,364), maka dapat disimpulkan bahwa hipotesa kerja diterima, yaitu "Ada Hubungan Antara Paritas Dengan Tingkat Kecemasan Ibu Hamil Trimester III Dalam Menghadapi Persalinan."

\section{Pembahasan}

\section{Paritas}

Tingkat paritas telah menarik perhatian para peneliti dalam hubungannya dengan kesehatan ibu dan bayi. Dikatakan bahwa terdapat kecenderungan kesehatan ibu yang berparitas rendah lebih baik daripada yang berparitas tinggi, terdapat asosiasi antara paritas dengan penyakit-penyakit tertentu
(Notoatmojo, Soekidjo. 2003 : 19). Menurut Sarwono (2005), paritas 2-3 merupakan paritas yang paling aman ditinjau dari sudut kematian maternal. Paritas 1 dan paritas tinggi (lebih dari 3) mempunyai angka kematian maternal lebih tinggi.

Nullipara adalah seorang wanita yang belum pernah melahirkan bayi viabel, artinya calon ibu tersebut belum pernah mempunyai pengalaman melahirkan dan mempunyai bayi sebelumnya. Oleh karena itu, sangat penting untuk memberikan parent educations, seperti persiapan yang diperlukan untuk menghadapi persalinan, baik persiapan moril maupun materil. Perlengkapan-perlengkapan ibu dan bayi yang dibutuhkan pada saat melahirkan hendaknya sudah dipersiapkan sebelum hari persalinan tiba. Kendaraan yang dipakai untuk mengantar ibu, siapa yang mendampingi ibu serta sarana dan tenaga kesehatan mana yang akan dituju, sebaiknya sudah dibicarakan dan diputuskan sebelum ibu melahirkan. Karena itu, diperlukan penjelasan dan informasi dari tenaga kesehatan khususnya bidan kepada ibu dan suami tentang hal tersebut pada saat ibu melakukan pemeriksaan ANC, sehingga pada saat persalinan baik ibu, suami, maupun keluarga sudah siap.

\section{Tingkat Kecemasan}

Suliswati (2005) menyatakan, pada tingkat kecemasan ringan dihubungkan dengan ketegangan yang dialami sehari-hari dimana individu masih waspada dan lapang persepsinya meluas. Pada tingkat kecemasan sedang individu berfokus hanya pada pikiran yang menjadi perhatiannya, terjadi penyempitan lahan persepsi, tetapi masih dapat melakukan sesuatu dengan arahan orang lain. Sedangkan pada tingkat kecemasan berat lapang persepsi menyempit, tidak dapat berpikir tentang halhal lain.

Dari hasil penelitian tidak ada satupun responden yang tidak mengalami kecemasan sama sekali. Suliswati (2005) menyatakan, secara umum individu tidak terlepas dari sressor dan pengalaman cemas, dimana timbulnya kecemasan tiap individu berbedabeda menurut tingkatannya. Perbedaan itu 
disebabkan karena tiap individu mempunyai pengalaman dalam menggunakan mekanisme koping. Carpenito (1999) menyatakan bahwa ansietas ringan diperlukan seseorang agar berfungsi dan berespon secara efektif terhadap lingkungan dan kejadian, kapasitas untuk menjadi cemas diperlukan untuk bertahan hidup.

Kecemasan atau ansietas tidak dapat dihindarkan dari kehidupan individu dalam memelihara keseimbangan dan kecemasan tersebut biasanya mengiringi ketakutan. Perasaan takut, kehati-hatian atau kewaspadaan yang tidak jelas dan tidak menyenangkan adalah salah satu manifestasi cemas yang dapat dialami oleh setiap orang terutama pada ibu hamil yang sedang menantikan proses persalinan. Hal itu wajar terjadi karena semakin tuanya umur kehamilan dan semakin dekatnya hari persalinan, maka semua ibu hamil tentunya akan mulai memikirkan dan mempersiapkan proses kelahiran bayinya.

Tingkat kecemasan pada setiap orang pasti berbeda-beda tergantung dari individu masing-masing. Pada tingkat kecemasan sedang individu terfokus hanya pada pikiran yang menjadi perhatiannya, terjadi penyempitan lahan persepsi, tetapi masih dapat melakukan sesuatu dengan arahan orang lain. Hal ini menunjukkan bahwa pada tingkat kecemasan sedang, ibu masih dapat dikatakan mengalami kecemasan pada batas normal, akan tetapi ibu juga sangat membutuhkan arahan atau bimbingan serta dukungan dari orang lain, khususnya orangorang terdekat yaitu suami dan keluarga, sehingga dapat mengurangi tingkat kecemasan ibu dalam menghadapi persalinan.

3. Hubungan Antara Paritas dengan Tingkat Kecemasan Ibu Hamil Trimester III dalam Menghadapi Persalinan

Dari hasil perhitungan terdapat hubungan antara paritas dan tingkat kecemasan ibu hamil trimester III dalam menghadapi persalinan.

Hasil penelitian juga menunjukkan bahwa nullipara merupakan paritas tertinggi yang mengalami kecemasan berat, sedangkan multipara merupakan paritas tertinggi yang mengalami kecemasan ringan.

Pada proses kejiwaan kehamilan trimester III timbul gejolak baru menghadapi persalinan dan perasaan tanggung jawab sebagai ibu terhadap bayi yang akan dilahirkan. Saat ini kehidupan psikologis dan emosional ibu hamil dipenuhi oleh pikiran dan perasaan mengenai persalinan dan tanggung jawab sebagai ibu (Mochtar, Rustam. 1998 : 179). Pada trimester III rasa cemas dan takut akan proses persalinan dan kelahiran meningkat. Ibu dihantui kecemasan menghadapi persalinan. Semakin bertambah dekatnya waktu persalinan akan membuat tingkat stres dan kecemasan ibu semakin meningkat (Sastranegara, Amanda, 2007).

Kuswandi (2007) menyatakan, semua orang selalu mengatakan bahwa melahirkan itu sakit sekali, oleh karena itu muncul ketakutan-ketakutan pada ibu yang baru pertama hamil dan belum memiliki pengalaman bersalin. Menurut Laili Arifin (2007) jika dilihat dari pengalaman melahirkan, ada dua golongan ibu yang diliputi rasa takut dan cemas mengahadapi persalinan. Golongan pertama adalah perempuan yang sudah pernah melahirkan, namun mempunyai pengalaman yang tidak menyenangkan pada kehamilan dan persalinan sebelumnya. Golongan kedua adalah ibu hamil pertama kali dan belum pernah mempunyai pengalaman melahirkan sebelumnya, tetapi banyak mendengar cerita-cerita dan pengalaman-pengalaman yang menakutkan dari orang lain tentang proses persalinan.

Pada saat umur kehamilan semakin tua, para ibu hamil mulai memikirkan proses persalinan yang akan dialaminya. Tidak sedikit para ibu hamil yang merasa cemas dan takut menghadapi proses persalinan. Oleh karena itu persiapan mental atau psikologis dalam menghadapi persalinan sangat penting dan jauh lebih baik bila dipersiapkan lebih awal sebelum proses persalinan tersebut berlangsung, sehingga ketika hari persalinan tiba ibu sudah siap menjalaninya dengan tenang tanpa rasa cemas dan takut. 
Kecemasan para ibu menghadapi persalinan salah satunya bisa disebabkan oleh ketakutan dan kecemasan menghadapi rasa sakit dan nyeri, apalagi bagi calon ibu yang belum pernah melahirkan sebelumnya (nullipara). Pengalaman rasa nyeri berbeda antara satu wanita dengan wanita yang lain, demikian pula antara persalinan pertama dengan persalinan berikutnya pada wanita yang sama ataupun pada wanita yang berbeda. Dengan semakin dekatnya jadwal persalinan, terutama pada persalian pertama, wajar timbul perasaan cemas ataupun takut. Untuk persalinan pertama, timbulnya kecemasan ini sangat wajar karena segala sesuatunya adalah pengalaman baru. Itulah salah satu penyebab sebagian besar yang mengalami kecemasan berat adalah nullipara dan kecemasan ringan kebanyakan dialami oleh multipara.

Pengalaman melahirkan sebelumnya turut ambil andil dalam mempengaruhi tingkat kecemasan seorang ibu dalam menghadapi proses persalinan. Bagi ibu yang belum pernah mempunyai pengalaman melahirkan sebelumnya (nullipara) banyak yang mengalami kecemasan berat, dikarenakan ibu takut akan pikiran dan bayangan sendiri tentang proses persalinan, ada pula yang banyak mendengar ceritacerita yang menakutkan tentang proses persalinan dari orang lain. Akan tetapi tidak menutup kemungkinan bagi para ibu yang sudah pernah mempunyai pengalaman melahirkan sebelumnya juga mengalami kecemasan, baik kecemasan ringan, sedang, maupun berat. Hal ini dapat disebabkan oleh pengalaman yang buruk pada persalinan sebelumnya, sehingga menyebabkan ibu merasa trauma dan takut menghadapi persalinan berikutnya.

\section{Kesimpulan}

1. Sebagian besar paritas yang ditemukan adalah nullipara sebanyak 43,33\%.

2. Tingkat kecemasan yang dialami oleh ibu hamil trimester III dalam menghadapi persalinan sebagian besar adalah kecemasan sedang sebanyak $43,33 \%$.

3. Dari analisa data menggunakan uji korelasi Spearman dengan interval kepercayaan $95 \%$ diperoleh hasil $\rho$ hitung lebih besar dari $\rho$ tabel $(0,553>$ 0,364), maka hipotesa kerja diterima yaitu "Ada hubungan antara paritas dengan tingkat kecemasan ibu hamil trimester III dalam menghadapi persalinan".

\section{Saran}

1. Bagi Lahan Penelitian

Penelitian ini dapat dijadikan bahan informasi dalam memberikan asuhan kebidanan yang tepat dan sesuai dengan asuhan sayang ibu untuk meminimalkan tingkat kecemasan ibu hamil dalam menghadapi persalinan, sehingga ibu sudah siap secara mental dan tenang dalam menghadapi persalinan yang dapat membantu kelancaran proses persalinan.

2. Bagi Penelitian Selanjutnya

Penelitian ini diharapkan dapat dijadikan acuan dan bahan informasi untuk melakukan riset kebidanan yang lebih spesifik lagi, mengingat banyak faktor lain disamping faktor paritas yang mempengaruhi tingkat kecemasan dalam menghadapi persalinan dan pada trimester III dapat dibagi lagi pada tiap minggunya yang tentunya perbedaan umur kehamilan tersebut juga ikut mempengaruhi tingkat kecemasan ibu hamil dalam menghadapi persalinan.

\section{Daftar Pustaka}

A. Aziz, Alimul. 2003. Riset Keperawatan dan Teknik Penulisan Ilmiah. Jakarta: Salemba Medika.

Andriana, Evarini. 2007. Kekhawatiran Saat Hamil. http://www.ibu hamil.com/new_design/lihat_artikel.php ?id/2008/03/07

Arifin, Laili. 2007. Menjalani Kehamilan Dengan Rileks. http://www.bagibagi.com/dewasa/2lahir/kontraksi.htm/2008/03/07

Arikunto, Suharsimi. 2005. Prosedur Penelitian Suatu Pendekatan Praktek. Jakarta: Rineka Cipta.

Aryasatiani. Ekarini. 2007. Mengapa Wanita Takut Menghadapi Persalinan?. 
http://www.gky.or.id/buletin/infosehat.h tm/2008/03/07

Dinas Pendidikan Nasional. 2002. Kamus Besar Bahasa Indonesia. Jakarta: Balai Pustaka.

Carpenito, L.J. 1998. Rencana Asuhan dan Dokumentasi Keperawatan. Jakarta: EGC.

Dorland. 2002. Kamus Kedokteran. Jakarta: EGC.

Farrer, Helen. 2001. Perawatan Maternitas. Jakarta: EGC.

Hasan, Iqbal. 2004. Analisa Data Penelitian Dengan Statistik. Jakarta: Bumi Aksara.

James, D.K. 2001. High Risk Pregnancy. Jakarta: EGC.

Jensen, Bobak. 2005. Keperawatan Maternitas. Jakarta: Hipokrates.

Mahasiswi Prodi Kebidanan Negeri Jakarta. 2002. Memberikan Asuhan Persalinan. http://www.hypno_birthing.web.id/2008 /03/07

Manuaba, IBG. 1998. Ilmu Kebidanan, Penyakit Kandungan dan Keluarga Berencana Untuk Pendidikan Bidan. Jakarta: EGC.

Mochtar, Rustam. 1998. Sinopsis Obstetri Jilid 1. Jakarta: EGC.

Notoatmojo, Soekidjo. 2003. Metodologi Penelitian Kesehatan. Jakarta: Rineka Cipta.

Nursalam. 2003. Konsep dan Penerapan Metodologi Penelitian Ilmu Keperawatan. Jakarta: Salemba Medika.

Prawirohardjo, Sarwono. 2002. Ilmu Kebidanan. Jakarta: YBP-SP.

Pusdiknakes. 2002. Saat-Saat Menghadapi Persalinan.

http://www.pusdiknakes.or.id./?show=d etailnews \&kode $=950 \&$ tbl=biaswanita $/ 2$ 008/03/07

Pusparini, Wening. 2003. Stres Menjelang Persalinan.

http://www.conectique.com/tips_solutio n/pregnancy/baby_dilevery?article.php? article_id=2933/2008/03/07

Sastranegara, Amanda. 2007. Keluhan Trimester Ketiga. http://www.bluefame.com/lofiversion/in dex.php/82112.html/2008/04/10
Stuart, Gail.W. 1998. Buku Saku Keperawatan Jiwa. Jakarta: EGC.

Sugiyono. 2005. Metode Penelitian Administrasi. Jakarta: Alfabeta.

Suheimi, K. 2007. Anamnesis Riwayat Psikoseksual.

http://www.ksuheimi.blogspot..com/200

7/10/anamnesis-riwayat-

psikoseksual.html/2008/04/10

Suliswati. 2005. Konsep Dasar Keperawatan Kesehatan Jiwa. Jakarta: EGC.

Razak, Matin Abdul. 2006. Program KB Indonesia Mendapat Pujian Internasional.

http://www.gerbang.jabar.go.id/2008/07 128

Wulandari, Primatia Y. 2007. Kehamilan Dan Persalinan Pertama. http://www.journal.unair.ac.id/filerFDT/ 2008/04/10

(HAMA). 2008. Hamilton Anxiety Scale http://www.anxietyhelp.org/information/ha ma.html/2008/04/14 